\title{
Ремоделювання великої підшкірної вени при посттромбофлебітичній хворобі
}

\author{
R. YA. BODNAR \\ SHEI "Ternopil State Medical University by I. Ya. Horbachevsky"
}

\section{REMODELING OF THE GREAT SAPHENOUS VEINAT CASE OF POSTTHROMBOFLEBITIC DISEASE}

\begin{abstract}
Проаналізовано особливості ремоделювання структурних компонентів великої підшкірної вени при посттромбофлебітичній хворобі. Встановлено такі особливості: тромбоз із формуванням капілярного ангіоматозу, переважання фібропластичних процесів за типом м’язово-еластичного і м'язово-фіброзного, циркулярного та осередкового звуження просвіту вени, неоаніогенез середньої оболонки, гіпереластоз із дискомплексацією еластичних волокон, набряк, лімфоцитарну інфільтрацію та морфологічні прояви капілярно-метаболічної недостатності.

We analyzed the features of remodeling of the structural components of the great saphenous vein in case of postthromboflebitic disease. We set the following features: thrombosis with formation of capillary angiomatosis, the predominance of sclerotic processes according to the type of muscular-elastic and muscular - fibrous, circular and focal narrowing of the lumen of the vein, angiogenesis of tunica media, hyperelastosis with dyscomplexation of elastic fibers, swelling, lymphocytic infiltration and morphological outcome of capillary-metabolic failure.
\end{abstract}

Постановка проблеми і аналіз останніх досліджень та публікацій. У хірургічній флебології постійно існувала і існує небезпека розвитку тромбоемболічних ускладнень у хворих на варикозну хворобу нижніх кінцівок. Проте в наш час ця особлива проблема, завдяки впровадженню рекомендацій щодопопередження тромбоемболій, підготовлених Американською колегією торакальних лікарів [1] та Національним інститутом здоров’я і клінічної досконалості [2], дещо покращилася [3]. Це зумовлено широким впровадженням антикоагулянтної та фібринолітичної терапії [4], а також з'ясуванням таких факторів ризику, як тривалість операційного втручання, вік та стать хворих, ожиріння, поліморбідність [5, 6, 7, 8, 9, 10]. Проте у структурі захворюваності відмічається тенденція до зростання чисельності посттромботичного синдрому. Частота даного пізнього ускладнення найбільш поширенаі коливається в межах 20-50 \% у пацієнтів, хворих на тромбоз глибоких вен, і в 7-10 \% супроводжується розвитком трофічних виразок, погіршенням якості життя [11]. Важливими передумовами посттромботичного синдрому вважають порушення реканалізації, рефлюкс і утруднення венозного відтоку та його взаємозв'язок із запальними маркерами IЛ-6, ICAМ-I $[12,13]$. Важливе місце в його морфогенезі належить структурній організації венозної стінки [14]. Проте останній аспект недостатньо висвітлений у наукових публікаціях і потребує як уточнення, так і доповнення $з$ позицій порушення метаболічних процесів у судинній стінці, що стало основою проведення нашого дослідження.

Мета роботи: з'ясувати морфологічні особливості ремоделювання компонентів стінки вен хворих, оперованих з приводу ретромбозу.

Матеріали і методи. Матеріалом для дослідження послужили фрагменти великої підшкірної вени, видаленої при хірургічному лікуванні ретромбозу в 10 пацієнтів (основна група). Групу контролю складали 5 випадків аутопсій без проявів варикозного ураження вени. Усі дослідження були проведені у мужчин віком від 34 до 55 років. Тканину піддавали стандартній передгістологічній обробці - фіксували у 10 \% нейтральному формаліні та ущільнювали парафіном. Гістологічні зрізи фарбували за загальноприйнятими методиками: гематоксиліном та еозином, пікрофуксином заметодом ванГізон, фукселіном Харта, трихромом за Масоном. Несульфатовані глікозаміноглікани ідентифікували альціановим синім за Стідменом, а сульфатовані глікозаміноглікани - PASреакцією.

Дослідження гістологічних препаратів здійснювали за допомогою мікроскопів SEOSCAN, Люнам Р-8 та МБИ-15 при різних рівнях збільшення. 
Зображення із мікроскопів виводили на монітор комп’ютера за допомогою відеокамери “Vision Color CCD Camera” і проводили фотографування об’єктів.

Результати досліджень та їх обговорення. При гістологічному дослідженні стінки великої підшкірної вени у контрольній групі встановлено типову ï структуру. Внутрішня оболонка вистелена ендотеліоцитами, які розміщуються на базальній мембрані. Еластичні волокна чітко контуруються. Внутрішня оболонка представлена лейоміоцитами, які формують циркулярний і повздовжній шари, розміщуються в пухкій сполучній тканині. Адвентиція контурується слабо, виявляються рихло розміщені колагенові волокна і повнокровні капіляри.

При гістологічному дослідженні великої підшкірної вени при посттромбофлебітичній хворобі виявлено такі морфологічні особливості: тромбоз із формуванням капілярного ангіоматозу, переважання фібропластичних процесів за типом м'язово-еластичногоі м'язово-фіброзного, циркулярного, осередкового звуження просвіту вени, неоангіогенез середньої оболонки, гіпереластоз із дискомплексацією еластичних волокон, набряк і лімфоцитарну інфільтрацію та морфологічні прояви капілярно-метаболічної недостатності.

Типовим морфологічним проявом структурної реорганізації венозної стінки були десквамація ендотеліального шару та потовщення інтими. Збережені ендотеліальні клітини набували веретеноподібної форми, цитоплазма яких гомогенна, ядра великі.

Потовщення інтими переважно зумовлене активацією фібропластичних процесів і характеризувалося як циркулярною, так і осередковою, частковою або субтотальною облітерацією просвіту. Циркулярна облітерація верифікувалася переважно в субклапанному сегменті і характеризувалася зростанням частки колагенових волокон та дифузним гіпереластозом із розволокненням еластичних волокон. Разом з тим у стромі спостерігали збільшення несульфатованих i сульфатованих глікозаміногліканів (рис. 1). При значно вираженому склерозі гіперплазованої інтими кількість глікозаміногліканів, сульфатованих і несульфатованих, була зниженою.

Осередкова облітерація просвіту переважно виявлялася в клапанному сегменті і характеризувалася як гіперпродукцією колагенових волокон, так i місцевою гіперплазією лейоміоцитів (рис. 2, А).

Характерною ознакоюдляданого типу облітерації $\epsilon$ пристінкова організація тромбу із формуванням ангіоматозу в ділянках організації пристінкового тромбу ( рис. 2, Б).

У середній оболонці венозної стінки при ретромбозі мали місце виражене збільшення колаге-

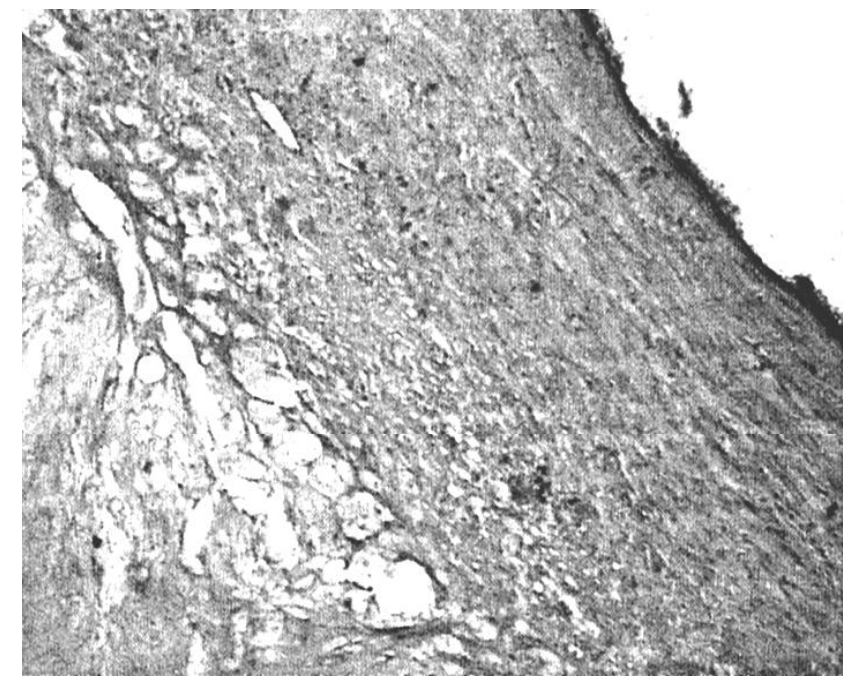

A

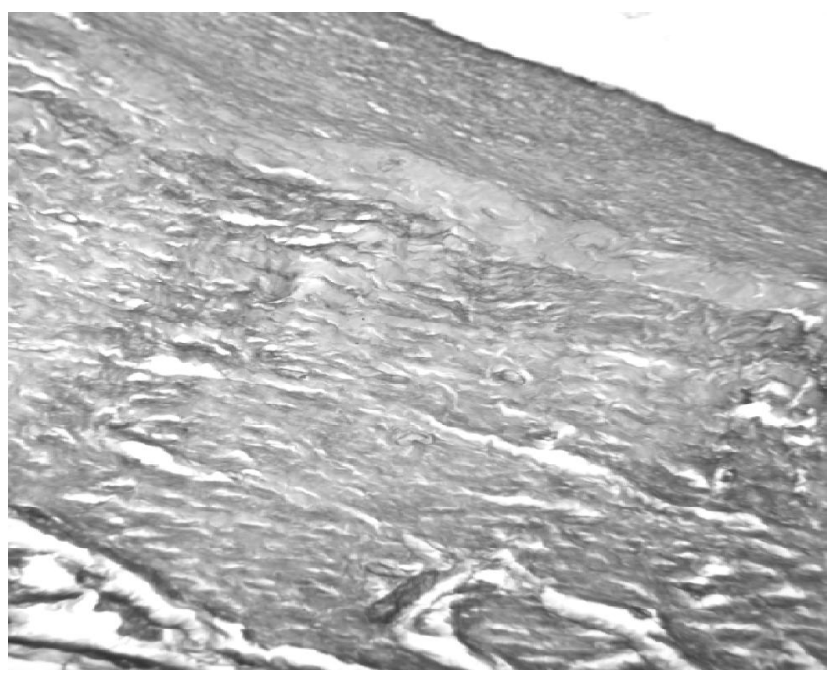

Б

Рис. 1. Надмірне накопичення несульфатованих і сульфатованих глікозаміногліканів у тканині стінки вени при посттромбофлебітичному синдромі. Гістологічний зріз великої підшкірної вени. Забарвлення: альціановим синім за Стідменом (А) та PAS-реакція (Б). Зб.: ок. 10, об. 10.

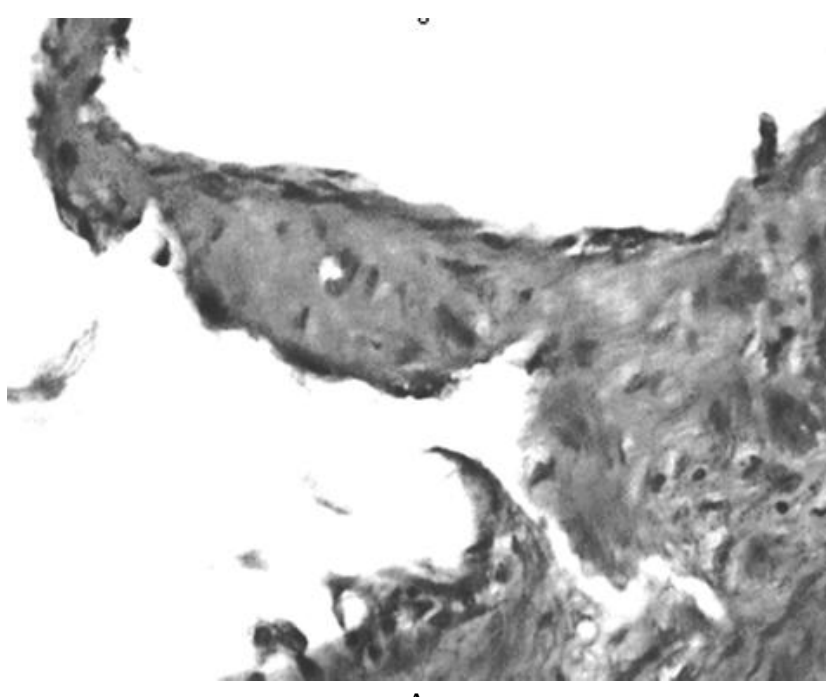

A 


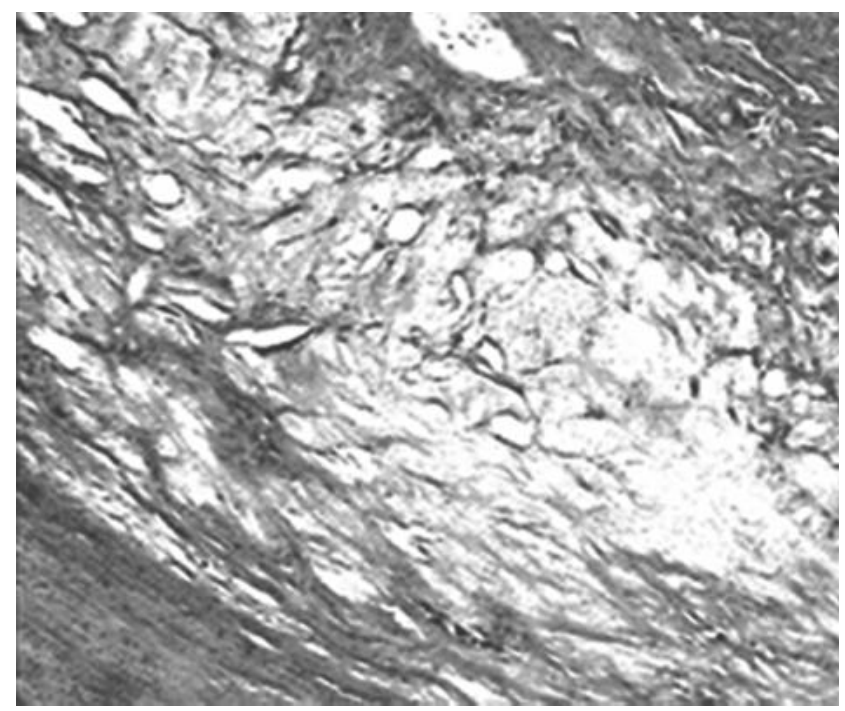

Б

Рис. 2. Гіперплазія і гіпертрофія лейоміоцитів у клапанному сегменті (А) та ангіоматоз у ділянці організації тромбу (Б). Гістологічний зріз великої підшкірної вени при посттромбофлебітичному синдромі. Забарвлення гематоксиліном та еозином. Зб.: ок. 10, об. 40.

нових волокон та атрофія гладких міоцитів. Характерною особливістю структурної реорганізації середньої оболонки великої підшкірної вени є наявність між лейоміоцитами новоутворених капілярів (рис. 3).

Просвіти їх звужені, не містять формених елементів крові. Проте ендотелій із збільшеним дещо гіперхромним ядром. На нашу думку, це свідчить про явища неоангіогенезу.

В основі неоваскуляризації середньої оболонки та прогресування фібропластичних процесів, ймовірно, лежить гіпоксичний механізм активації фібробластів, що стверджується і структурними змінами адвентиції.

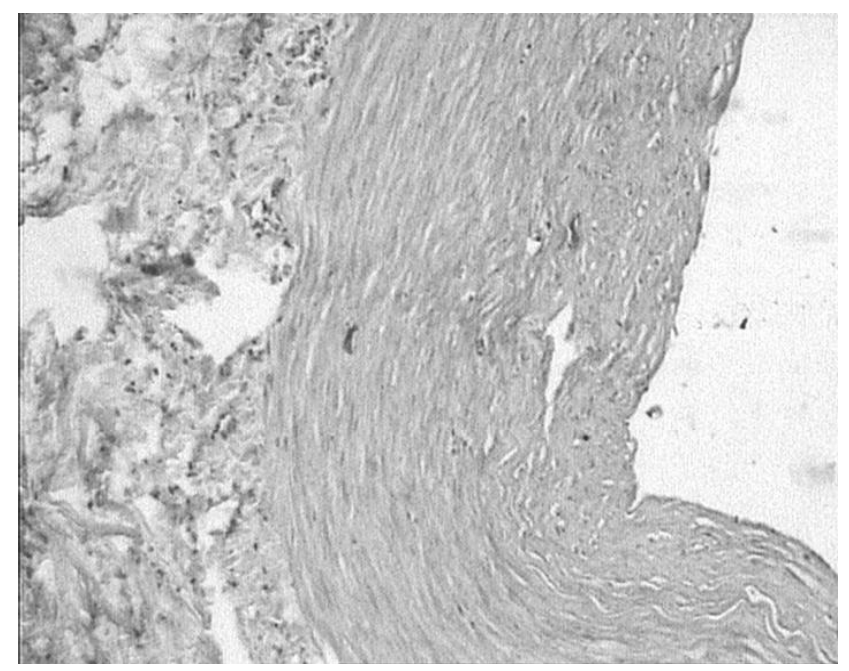

Рис. 3. Неоангіогенез у середній оболонці великої підшкірної вени. Гістологічний зріз великої підшкірної вени при посттромбофлебітичному синдромі. Забарвлення гематоксиліном та еозином. Зб.: ок. 10, об. 10.
Гістологічно в адвентиції теж переважали склеротичні процеси. Значно збільшувалася кількість потовщених колагенових волокон. Частина судин була облітерована, у частини просвіти були розширені та повнокровні, що $є$ проявом капілярно-метаболічної недостатності, яка зумовлювала гіпоксичний стан судинної стінки і сприяла розвитку атрофічних i склеротичних процесів. Важливою ланкою морфогенезу останніх є також набряк і лімфогістіоцитарна інфільтрація як у ділянці організації тромбу, так і в адвентиції (рис. 4).

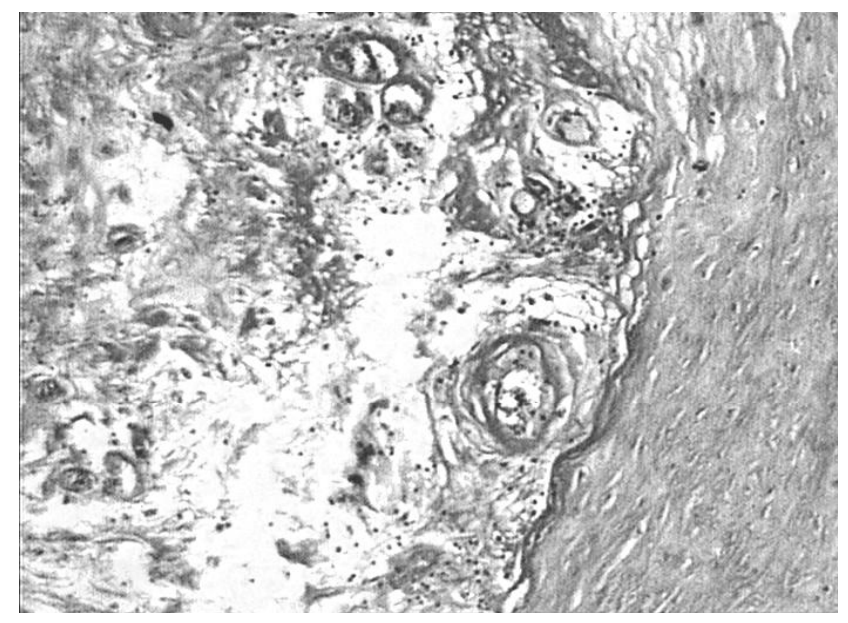

Рис. 4. Набряк, лімфоцитарна інфільтрація перивазальної клітковини, розширення й облітерація просвіту судин. Гістологічний зріз великої підшкірної вени при посттромбофлебітичному синдромі. Забарвлення гематоксиліном та еозином. Зб.: ок. 10, об. 10.

Висновки. 1. Ремоделювання великої підшкірної вени при посттромбофлебітичній хворобі характеризується неспецифічними фібропластичними процесами інтими, середньої оболонки й адвентиції у поєднанні 3 атрофією лейоміоцитів і проявляється як циркулярним, так і осередковим звуженням просвіту судини.

2. До морфологічних особливостей структурної перебудови венозної стінки при посттромбофлебітичній хворобі слід віднести накопичення сульфатованих і несульфатованих глікозаміногліканів у всіх оболонках судини, гіперплазію лейоміоцитів у клапанному сегменті, неоваскуляризацію медії.

3. Десквамацію ендотеліоцитів, порушення ламінарності судинної стінки, лімфогістіоцитарну інфільтрацію та морфологічні прояви капілярно-метаболічної недостатності можна вважати предикторами ретромбозу.

Перспективи подальших досліджень. Морфологічні дані стосовно ремоделювання великої підшкірної вени доцільно розширити методом електронної мікроскопії і з'ясувати особливості їх взаємозв'язку із гемостазіологічними показниками та частотою розвитку ретромбозу. 


\section{СПИСОК ЛІТЕРАТУРИ}

1. Prevention of venous thromboembolism: American College of Chest Physicians Evidence-Based Clinical Practice Guideline ( ${ }^{\text {th }}$ Edition) / W. H. Greet, D. Bergqvist, G. F. Pineo [et al.] // Chest. - 2008. Vol. 133. - (Suppl 6. - P. 381-453.

2. National Institute for Health and Clinical Excellence. Venous thromboembolism: Reducing the risk of venous thromboembolism (deep vein thrombosis and pulmonary embolism) in patients admitted to hospital. January 2010. / http: www.nice.org.uk/ niecmedia/pdf/cg92FullGuideline.pdf.

3. Профилактика послеоперационных венозных тромбоэмболических осложнений в российских стационарах (предварительные результаты проекта “Территория безопасности”) / В. С. Савельев, А. И. Кириенко, И. А. Золотухин [и др.] // Флебология. - 2010. - № 3. - С. 3-6.

4. Лікування флеботромбозів системи нижньої порожнистої вени, ускладнених флотацією верхівки тромбу / I. I. Кобза, Б. М. Наврилів, Ю. Г. Орел [та ін.] // Науковий вісник Ужгородського університету. - 2012. - Вип. 2 (44). - С. 47-48. (Серія “Медицина”).

5. Тромбоз глубоких вен. От патогенеза к лечению / Л. М. Чернуха, А. А. Гуч, П. И. Никульников [и др.] // Клінічна флебологія. - 2011. - Т. 4, № 1. - С. 113-116.

6. Хрыщанович В. Я. Посттромботическая болезнь: диагностика, лечение, профилактика / В. Я. Хрыщанович // Новости хирургии. - 2013. - Т. 21, № 3. - С. 120-128.

7. Ризюк М. Д. Порівняльна оцінка скринінгових показників коагуляційного гемостазу у хворих на гострий тромбофлебіт нижніх кінцівок / М. Д. Ризюк // Шпитальна хірургія. -2014.
- № 1. - C. 28-31.

8. Investigator. Subcutaneous adjusted - dose unfractionated heparin vs fixed - dose low molecular - weight heparin in the initial treatment of venous thromboembolism / P. Prandoni, M. Carnovali, Marchiori [et al.] // Arch. Intern. Med. - 2004. - Vol. 164 - P. 1007-1083.

9. Long - Term Survival in a Large Cohort of Patients which Venous Thrombosis: Incidence and Predictors / L. E. Flinterman, A. Vlieg van H., S. C. Cannegieter [et al.] // Plos. Med. - 2012. Vol. 9(1). - P. 100-155.

10. Perler B. Thrombolytic therapies: the current state of affairs / B. Perler // J. Endovasc. Ther. - 2005. - Vol. 3, № 12. - P. 224 232.

11. Singh $\mathrm{H}$. Comparing short-term outcomes of femoral popliteal and ilio-femoral deep venous thrombosis early lysis and development of reflux / H. Singh, E. M. Masuda // Ann. Vasc. Surg. - 2005. - Vol. 19, № 1. - P. 74-79.

12. Prandoni P. Post-thrombotic syndrome: prevalence, prognostication and need for progress / P. Prandoni, S. R. Kahn // Br. J. Haematol. - 2009. - Vol. 145, № 3. - P. 286-295.

13. Roumen-Klappe E. M. Inflammation and deep vein thrombosis and the development of post-thrombotic syndrome: a prospective study / E. M. Roumen-Klappe // J. Thromb Haemost. - 2009. - Vol 7, № 4. - P 582-587.

14. Иммуноморфологические особенности строения стенки большой подкожной вены у больных, страдающих осложненной варикозной болезнью / И. В. Сорокина, В. А. Прасол, В. И. Троян [и др.] // Патология. - 2010. - Т. 7, № 2. - 85-90.

Отримано 17.03.15 